\title{
Impact of Goods and Services Tax on Indirect Tax Revenue of India: With Special Reference to Odisha State
}

\author{
Sanjeeb Kumar Dey ${ }^{1,2}$ \\ ${ }^{1}$ OURIIP Seed Fund Research Project, OSHEC, India \\ ${ }^{2}$ Department of Commerce, Ravenshaw University, India
}

Received April 12, 2021; Revised May 13, 2021; Accepted June 20, 2021

\section{Cite This Paper in the following Citation Styles}

(a): [1] Sanjeeb Kumar Dey, "Impact of Goods and Services Tax on Indirect Tax Revenue of India: With Special Reference to Odisha State," Universal Journal of Accounting and Finance, Vol. 9, No. 3, pp. 431 - 441, 2021. DOI: 10.13189/ujaf.2021.090318.

(b): Sanjeeb Kumar Dey (2021). Impact of Goods and Services Tax on Indirect Tax Revenue of India: With Special Reference to Odisha State. Universal Journal of Accounting and Finance, 9(3), 431 - 441. DOI: 10.13189/ujaf.2021.090318.

Copyright $\bigcirc 2021$ by authors, all rights reserved. Authors agree that this article remains permanently open access under the terms of the Creative Commons Attribution License 4.0 International License

\begin{abstract}
Goods and Services Tax is considered to be one of the revolutionary tax reforms in India since independence. The foundation of this new taxation system is to remove the cascading effect and increase the tax revenue with more transparent mechanism. The present paper is an attempt to assess the impact of this new taxation system on indirect tax revenue of India in general and of Odisha in specific. The study is analytical in nature and is based on published data. Collection of revenue under goods and services taxes has been considered from July 2017 to March 2021. The results show an increasing trend of indirect tax in India due to implementation of new tax except a few months because of some administration complexity and prevailing Corona pandemic. Future tax revenues have been forecasted using Exponential Triple Smoothing function and are compared with actual collection up to March 2021. So far Odisha state is concerned, expected tax revenue is not yet realised and the situation may be unfavourable when Central Government will stop giving Compensation cess after July 2022.
\end{abstract}

Keywords GST, India, Odisha, Forecasting, ETS Functions

\section{Introduction}

Taxation system is an incredible tool in the hands of any
Government to establish vertical equity through income redistribution or reduce the gap between the rich and the poor. It refers to a mandatory levy by the Government on its citizen either on their income i.e., income tax or on consumptions or productions i.e., value added tax, services tax and custom duty to meet the financial requirement for social and economic development activities of the country. It constitutes a fundamental source of revenue to stimulate the economic and social development strategies. At present, India has very limited direct taxation system like the Income Tax, Dividend distribution tax, securities transactions tax, etc. However, there were more than twenty-seven types of indirect taxation system in India which includes value added tax, customs duty, exercise duty, services tax, entry tax, entertainment tax, and so on still July 2017 i.e., introduction of goods and services tax. On an average more than sixty-five percentage of total tax revenue arises from indirect tax revenue.

The income tax gets amended every year along with the Union Budget through the finance bill to bring more uniformity and ease of compliance of taxation. These changes are also done with a view to bring more taxpayers under its scope and check the avenues of tax evasions. There was also an attempt for reconstruction of direct taxation system in India during 2009 to introduce Direct Tax Code but is not yet materialized. On the other hand, there are so many indirect taxes and each one having overlapping applicability, creates confusion and 
discourage among the users to do business in India. The existing indirect tax system was characterized with double taxation due to cascading effect, complex procedure, multiple taxation system, non-availability of tax credit throughout the value change, etc. With a view to eliminate these shortcomings, Government of India has introduced Goods and Services Tax under the banner of "one nation- one tax- one market" with effect from 1st July 2017 after fourteen years of deliberations and discussions which is applicable to the whole of India. It is considered to be the biggest and revolutionary tax reform since our independence (Garg \& Kumar [6], Kawale \& Aher [8], Patil [20], Tiwari \& Singh [29]). It subsumes almost all indirect taxes lived by the States and Central Government and resulted into one tax i.e., Goods and Services Tax.

Since its first implementation by France in 1954, Goods and Services tax proves to the mechanism that has the capacity to increase the revenue in most neutral and transparent manner. Till date, more than 160 countries in the World have adopted this tax in one form or other. The transition from the old system to this new uniform taxation system was smoother in most of the countries as mostly taxes lived by the Central Government like Australia and Germany. Country like India where imposition of taxation lies with both the Central and State Government will obviously take time to settle down as witness by countries like Brazil, Canada and the European Union where even after years of experience in these countries, the reform is a work in progress. In Canada, Bird [3] argues that the transition has not been easy and even after 28 years of experience it is still a work in progress.

This new taxation system is characterized by seamless claim of input tax credit throughout the value chain, destination-based taxation as against origin-based taxation, avoiding double taxation resulted from cascading effects, more transparency system, increased ease of doing business, simpler and use friendly compliance, digital platform, increase the revenue base, etc. (Beri [2], Leena \& Sameena [10], Nayyar \& Singh [18]. Petroleum products, alcohol for human consumption, aviation turbine fuel, high speed diesel motor spirit and natural gas are kept outside the scope of this new taxation. GST is going to celebrate its fourth anniversary during July 2021, but still the system requires continuing changes to bring transparency and ease of compliance with law. Nevertheless, the time is fitting to take stock of the progress in implementing the tax, analyse its revenue implications and economic impact and identify further challenges and reform areas to reach the goal of raising revenue productivity and minimising cost.

\section{Literature Review}

\subsection{Impact of GST on Tax Revenue}

In the words of Mukherjee [12] viewed that the triumph of GST, in terms of compliance and mustering of revenue, is dependent on simplified tax administration process and incentivising transactions with tax invoices. In another study, Mukherjee [13] concluded that while the removal of GST compensation cess (GSTCC) will benefit some states, others might not be that beneficial. If the GST compensation is terminated in 2022 then the government needs an appropriate framework for strengthening various aspects of GST. Charan et al. [5] concluded that GST is expected to bring simplification in the accounting process and paperwork of business organisations, facilitate equal distribution of revenue between the states and centre, significantly improve trade and commerce and thereby develop the economy. In addressing the governance aspect of GST in Malaysia, Sanusi [25] suggested that the country will not be dependent on overseas loan if the government revenue is well collected, smartly managed and fairly distributed. Information technology plays a major role in the launch of a new tax regime. Every country which introduced GST was more or less dependent on their IT infrastructure. In case of Malaysia, the government was able to collect more GST revenue because of strong IT infrastructure (Mansoor et al., [11]). According to Tewari [28], GST will lessen the tax burden, bring transparency, increase government revenue by expanding tax base, eliminate the roadblock of multiple tax barriers and foster the development of exports. In their paper, Purohit and Purohit [22] estimated central GST revenue with the help of three approaches which are revenue, turnover and consumption approach. As per their suggestion, ample amount of GST revenue can be collected if the government charges $8 \%$ dual rate for both CGST and SGST. The government should also charge the necessity items at a lower rate of $4 \%$.

Rao [24] searched for the answer to whether GST is a gorilla or chimpanzee or a primate. His pursuit of the answer showed that the introduction of GST was imperative as it can help in minimising the compliance costs, collection cost as well as the cost of resource allocation. GST can also help in raising additional tax revenue in the medium run. He reached at the conclusion that GST is a genius like a primate not a gorilla or chimpanzee. In the words of Alappatt and Shaikh [1], GST is a sustainable source of revenue for Malaysia. During the initial phase GST may cause inflation but it will subside after very few years. The proper implementation of GST will expand the tax base, increase government revenue and help the public in managing their tax burden. Khoja and Khan [9] the role of GST in reducing the cascading effect and its impact on revenue performance of commodity taxation market of India. By collecting time series data from 1990 to 2017 and applying simultaneous equation model they found that the enforcement of GST in India has caused a decrease in cascading and ameliorated the revenue performance of the commodity tax structure. In the post GST years, the central and state government have performed better in terms of tax revenue collection. Stewart et al. [27] propounded that GST was an 
improvement over the current tax system of Australia. Chakraborty [4] reported that GST can improve the exports of the Indian textile industry. This new system has also bunged the revenue leakage of the previous tax system. It has reduced the ultimate tax burden of the taxpayers, eliminated the cascading effect, and provided smooth flow of input tax credit which was not available in the previous taxation system. Nayaka and Panduranga [17] reported that GST has increased the amount of indirect tax revenue of the nation but it has lessened the tax revenues of the Karnataka state. In another study, Mukherjee [15], [16] focused on assessing the effect of pandemic on the GST revenue of the states and union and also tried to estimate the amount of GST revenue and compensation cess. He reported that the total GST collection of all major states will vary between the approximate rates of -3.3 and -12.3 percent.

\subsection{Impact of GST on Cost and Compliance}

Rao [23] opined that the Indian government can increase the tax revenue by minimising the compliance cost, the cost of collection and the economic costs. Pandey [19] suggested that the government should also have a general consent regarding the threshold limit, revenue rate and inclusion of liquor, petroleum products, real state and electricity in the GST structure. Pegu [21] viewed that the real victory of Indian GST can be determined only after evaluating its effect on the general consumers. He also propounded that GST can simplify the taxation system only when there is a general agreement on the revenue rate, threshold limit, and inclusion of some products in the GST structure. Mukherjee [14] has analysed the performance of GST in terms of revenue and compliance gap at both national and state level. His study indicated a gap in the filing rate of GSTR-1 and GSTR-3B which has caused problems for claim of input tax credit. Odisha is in the second position regarding the compliance gap during the author's period of study. Minor states have outperformed the major states in GST compliance gap. In the words of Singh [26], GST will make compliance easy, bring uniformity in the tax structure, remove the cascading nature of taxes, improve competitiveness among business, and help both state and central government to improve revenue efficiency and is easy to implement. According to Holla [7], the strengths of Indian GST are that it is simple, boots government revenue, makes that market uniform, causes rise in capital investment, etc. GST will bring the opportunity of removal of cascading effect, reduction in consumer tax burden, etc.

Most of the earlier studies concentrate on overall implication of GST on economy. Many studies attempt to study the theoretical aspects, procedural aspects and revenue implication. Seldom any work finds the growth and impact of GST on indirect tax revenue over these four years of implementation. Considering the above discuss, the following hypotheses have been framed to be tested in this study:

H1: There is a significant increase in the indirect tax revenue during GST regime.

$\mathrm{H} 2$ : There is no significant difference between forecasted and actual revenue.

\section{Objectives \& Methods}

\subsection{Objectives of Study}

The primary focus of the study is to access the impact of goods and services tax on tax revenue of India in general and of Odisha state in particular. The paper also focuses on forecasting the GST revenue for the upcoming years based on the historical data.

\subsection{Nature of Study}

The study is analytical in nature and based on purely secondary data. It covers nine years spreading from 2013 to 2021. All the data have been collected from the official website of the central board of indirect taxes and customs, India, Press Information Bureau, Government of India and Commissionerate of CT and GST, Government of Odisha.

\subsection{Scope of Study}

The study covers various aspects of India and Odisha State. Odisha is the $8^{\text {th }}$ largest state by area, $11^{\text {th }}$ largest state by population and $16^{\text {th }}$ largest state by economy representing 750 billion USD situated in the eastern part of India (PRS India, 2020). Further, as per number of active taxpayers registered under GST as on 31 December 2020, Odisha stood almost median out of total 39 states in India representing $2.20 \%$. Considering the above facts, Odisha state has been given special focus which will represent the overall GST scenario.

\subsection{Variables Considered}

For achieving the objectives of this study, revenue variables i.e., Central Goods and Services Tax, State Goods and Services Tax, Integrated Goods and Services Tax, State Compensation Cess, Active Taxpayers and GST Returns.

\subsection{Techniques Adopted}

All data collected have been suitably tabulated in a comparative manner and appropriate charts are also used. For the purpose of achieving the objectives, simple average, growth rate, t-test, Exponential Triple Smoothing techniques for forecasting future values have been used. MS-Office 2019 and SPSS tools have been used to analyse 
the data.

\section{Results and Discussion}

It is prominent from table-1 that there is considerable increase in the number of registered taxpayers under GST. As on 31 December total 278645 numbers of active taxpayers registered under Odisha which a growth rate of $8.94 \%$ as against last financial year which is double of All India growth rate. On the contrary total number of active taxpayers in India is 10782730 as on 31 December 2020 with a yearly growth rate of $4.01 \%$.

Table-2 and Figure-1 show the comparative trend of number of returns by the active taxpayers during last four years. GSTR-1 i.e., furnishing details of outward supply are filed by minimum $76 \%$ of eligible taxpayers in Odisha while the same is $80 \%$ in all India basis. Similarly, GSTR-3B i.e., monthly returns for all regular taxpayers is almost the same by both Odisha and India as a whole. The return filing efficiency of Odisha taxpayers is definitely not at par with the all-India level.

Table 1. Comparative Status of Active Taxpayers under GST

\begin{tabular}{|c|c|c|c|c|}
\hline & \multicolumn{2}{|c|}{ Odisha (State Level) } & \multicolumn{2}{c|}{ India (Federal Level) } \\
\hline Date & $31-12-2019$ & $31-12-2020$ & $31-12-2019$ & $31-12-2020$ \\
\hline Normal Taxpayers & $2,22,058$ & $2,44,241$ & $1,03,19,462$ & $1,07,82,730$ \\
\hline Composition Taxpayers & 30,570 & 30,527 & $16,83,706$ & $16,89,081$ \\
\hline ISD & 77 & 58 & 8,179 & 7,094 \\
\hline Casual Taxpayers & 15 & 3 & 1,872 & 533 \\
\hline TCS & 141 & 200 & 8,243 & 11,574 \\
\hline TDS & 2,873 & 3,573 & $1,75,446$ & $1,95,511$ \\
\hline NRI & 1 & 0 & 23 & 27 \\
\hline OIDAR & 0 & 0 & 366 & 249 \\
\hline UIN Holders & 43 & 43 & 2,235 & 2,276 \\
\hline Total & $2,55,778$ & $2,78,645$ & $1,21,99,532$ & $1,26,89,075$ \\
\hline YoY Growth & & $8.94 \%$ & & $4.01 \%$ \\
\hline
\end{tabular}

Source: cbic.gov.in and odishatax.gov.in

Table 2. Comparative growth of returns in GST

\begin{tabular}{|c|c|c|c|c|c|c|c|}
\hline & & \multicolumn{3}{|c|}{ Odisha } & \multicolumn{3}{c|}{ India } \\
\hline $\begin{array}{c}\text { Return } \\
\text { Forms }\end{array}$ & $\begin{array}{c}\text { Year } \\
\text { ending }\end{array}$ & $\begin{array}{c}\text { No. of Eligible } \\
\text { Tax Payers }\end{array}$ & $\begin{array}{c}\text { Total Returns } \\
\text { Filed }\end{array}$ & Percentage & $\begin{array}{c}\text { No. of Eligible } \\
\text { Tax Payers }\end{array}$ & $\begin{array}{c}\text { Total Returns } \\
\text { Filed }\end{array}$ & Percentage \\
\hline \multirow{4}{*}{ GSTR-1 } & Mar-18 & $1,83,516$ & $1,50,000$ & $81.74 \%$ & $84,55,633$ & $76,34,528$ & $90.29 \%$ \\
\cline { 2 - 8 } & Mar-19 & $2,18,115$ & $1,74,444$ & $79.98 \%$ & $1,01,74,978$ & $85,77,608$ & $84.30 \%$ \\
\cline { 2 - 8 } & Mar-20 & $2,23,069$ & $1,70,134$ & $76.27 \%$ & $1,04,30,804$ & $83,47,493$ & $80.03 \%$ \\
\cline { 2 - 8 } & Dec-20 & $1,15,490$ & 55,312 & $47.89 \%$ & $53,48,268$ & $31,81,281$ & $59.48 \%$ \\
\hline \multirow{5}{*}{ GSTR-3B } & Mar-18 & $1,83,516$ & $1,61,776$ & $88.15 \%$ & $84,55,633$ & $79,05,882$ & $93.50 \%$ \\
\cline { 2 - 8 } & Mar-19 & $2,18,115$ & $1,92,320$ & $88.17 \%$ & $1,01,74,978$ & $89,98,036$ & $88.43 \%$ \\
\cline { 2 - 8 } & Mar-20 & $2,23,069$ & $2,09,677$ & $94.00 \%$ & $1,04,30,804$ & $94,92,529$ & $91.00 \%$ \\
\cline { 2 - 8 } & Dec-20 & $2,47,799$ & $1,96,664$ & $79.36 \%$ & $1,10,10,573$ & $87,15,834$ & $79.16 \%$ \\
\hline
\end{tabular}

Source: cbic.gov.in and odishatax.gov.in

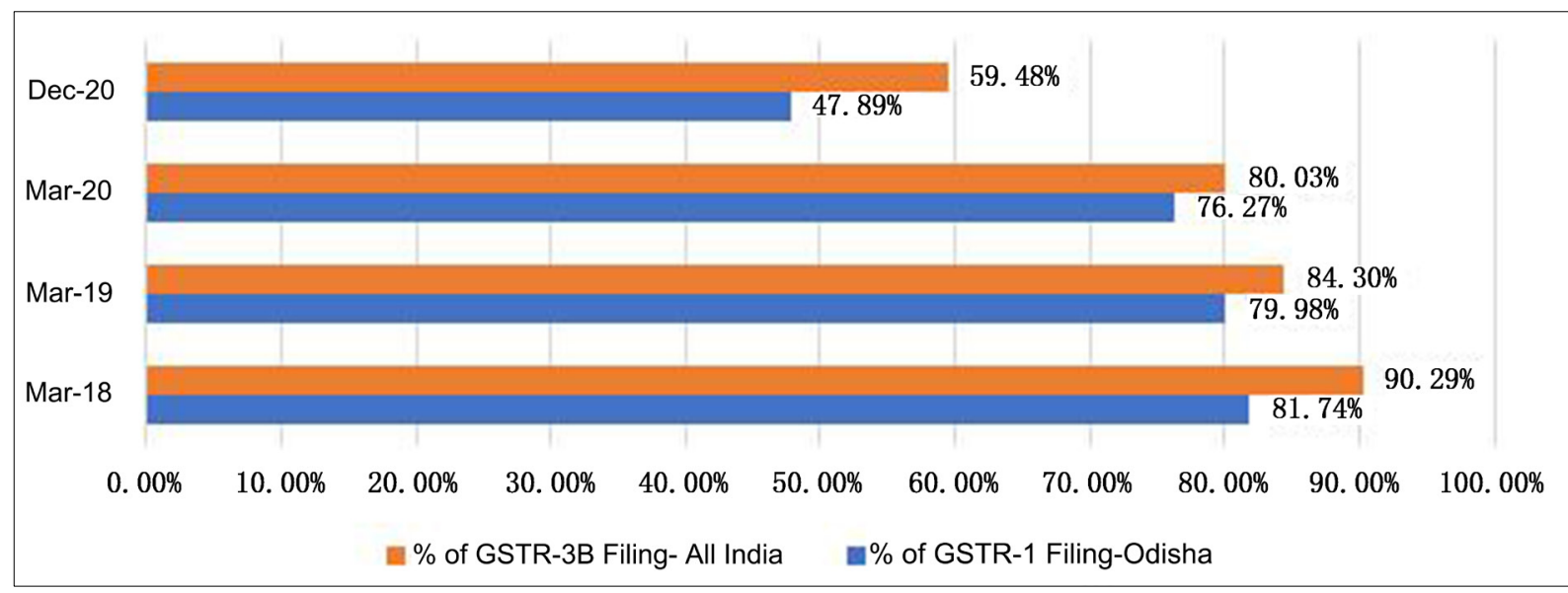

Figure 1. Comparative trend in percentage of returns in GST 
Table 3. Growth of Component wise GST Collections in India (Rupees in Crore)

\begin{tabular}{|c|c|c|c|c|c|c|}
\hline Year & CGST & SGST & IGST & Cess & Total & M-O-M Change \\
\hline Jul-17 & 10 & 10 & 20958 & 594 & 21572 & \\
\hline Aug-17 & 15252 & 23257 & 49968 & 7156 & 95633 & $343.3 \%$ \\
\hline Sep-17 & 15131 & 21979 & 48930 & 8024 & 94064 & $-1.6 \%$ \\
\hline Oct-17 & 14962 & 22345 & 47995 & 8031 & 93333 & $-0.8 \%$ \\
\hline Nov-17 & 13690 & 20294 & 42694 & 7102 & 83780 & $-10.2 \%$ \\
\hline Dec-17 & 13928 & 19700 & 42765 & 7921 & 84314 & $0.6 \%$ \\
\hline Jan-18 & 14874 & 21542 & 45338 & 8071 & 89825 & $6.5 \%$ \\
\hline Feb-18 & 14763 & 20621 & 42382 & 8196 & 85962 & $-4.3 \%$ \\
\hline Mar-18 & 16266 & 22055 & 46326 & 7520 & 92167 & $7.2 \%$ \\
\hline Apr-18 & 18653 & 25704 & 50548 & 8554 & 103459 & $12.3 \%$ \\
\hline May-18 & 15866 & 21691 & 49120 & 7339 & 94016 & $-9.1 \%$ \\
\hline Jun-18 & 15968 & 22021 & 49498 & 8123 & 95610 & $1.7 \%$ \\
\hline Jul-18 & 15877 & 22293 & 49951 & 8362 & 96483 & $0.9 \%$ \\
\hline Aug-18 & 15303 & 21154 & 49875 & 7628 & 93960 & $-2.6 \%$ \\
\hline Sep-18 & 15318 & 21061 & 50070 & 7993 & 94442 & $0.5 \%$ \\
\hline Oct-18 & 16464 & 22826 & 53419 & 8001 & 100710 & $6.6 \%$ \\
\hline Nov-18 & 16812 & 23070 & 49726 & 8029 & 97637 & $-3.1 \%$ \\
\hline Dec-18 & 16442 & 22459 & 47936 & 7889 & 94726 & $-3.0 \%$ \\
\hline Jan-19 & 17763 & 24826 & 51225 & 8689 & 102503 & $8.2 \%$ \\
\hline Feb-19 & 17625 & 24192 & 46953 & 8477 & 97247 & $-5.1 \%$ \\
\hline Mar-19 & 20353 & 27520 & 50418 & 8286 & 106577 & $9.6 \%$ \\
\hline Apr-19 & 21163 & 28801 & 54733 & 9168 & 113865 & $6.8 \%$ \\
\hline May-19 & 17811 & 24462 & 49891 & 8125 & 100289 & $-11.9 \%$ \\
\hline Jun-19 & 18366 & 25343 & 47772 & 8457 & 99938 & $-0.3 \%$ \\
\hline Jul-19 & 17912 & 25008 & 50612 & 8551 & 102083 & $2.1 \%$ \\
\hline Aug-19 & 17733 & 24239 & 48958 & 7273 & 98203 & $-3.8 \%$ \\
\hline Sep-19 & 16630 & 22598 & 45069 & 7620 & 91917 & $-6.4 \%$ \\
\hline Oct-19 & 17582 & 23674 & 46517 & 7607 & 95380 & $3.8 \%$ \\
\hline Nov-19 & 19592 & 27144 & 49028 & 7727 & 103491 & $8.5 \%$ \\
\hline Dec-19 & 19962 & 26792 & 48099 & 8331 & 103184 & $-0.3 \%$ \\
\hline Jan-20 & 20944 & 28224 & 53013 & 8637 & 110818 & $7.4 \%$ \\
\hline Feb-20 & 20569 & 27348 & 48503 & 8947 & 105367 & $-4.9 \%$ \\
\hline Mar-20 & 19183 & 25601 & 44508 & 8306 & 97598 & $-7.4 \%$ \\
\hline Apr-20 & 6325 & 8439 & 14670 & 2738 & 32172 & $-67.0 \%$ \\
\hline May-20 & 12219 & 16302 & 28341 & 5289 & 62151 & $93.2 \%$ \\
\hline Jun-20 & 18980 & 23970 & 40302 & 7665 & 90917 & $46.3 \%$ \\
\hline Jul-20 & 16147 & 21418 & 42592 & 7265 & 87422 & $-3.8 \%$ \\
\hline Aug-20 & 15906 & 21064 & 42264 & 7215 & 86449 & $-1.1 \%$ \\
\hline Sep-20 & 17741 & 23131 & 47484 & 7124 & 95480 & $10.4 \%$ \\
\hline Oct-20 & 19193 & 25411 & 52540 & 8011 & 105155 & $10.1 \%$ \\
\hline Nov-20 & 19189 & 25540 & 51992 & 8242 & 104963 & $-0.2 \%$ \\
\hline Dec-20 & 21365 & 27804 & 57426 & 8579 & 115174 & $9.7 \%$ \\
\hline Jan-21 & 21923 & 29014 & 60288 & 8622 & 119847 & $4.1 \%$ \\
\hline Feb-21 & 21092 & 27273 & 55253 & 9525 & 113143 & $-5.6 \%$ \\
\hline Mar-21 & 22973 & 29329 & 62842 & 8757 & 123901 & $9.5 \%$ \\
\hline Average & 16929 & 23079 & 47306 & 7728 & 95043 & \\
\hline
\end{tabular}

Source: www.pib.gov.in/press release various issues 


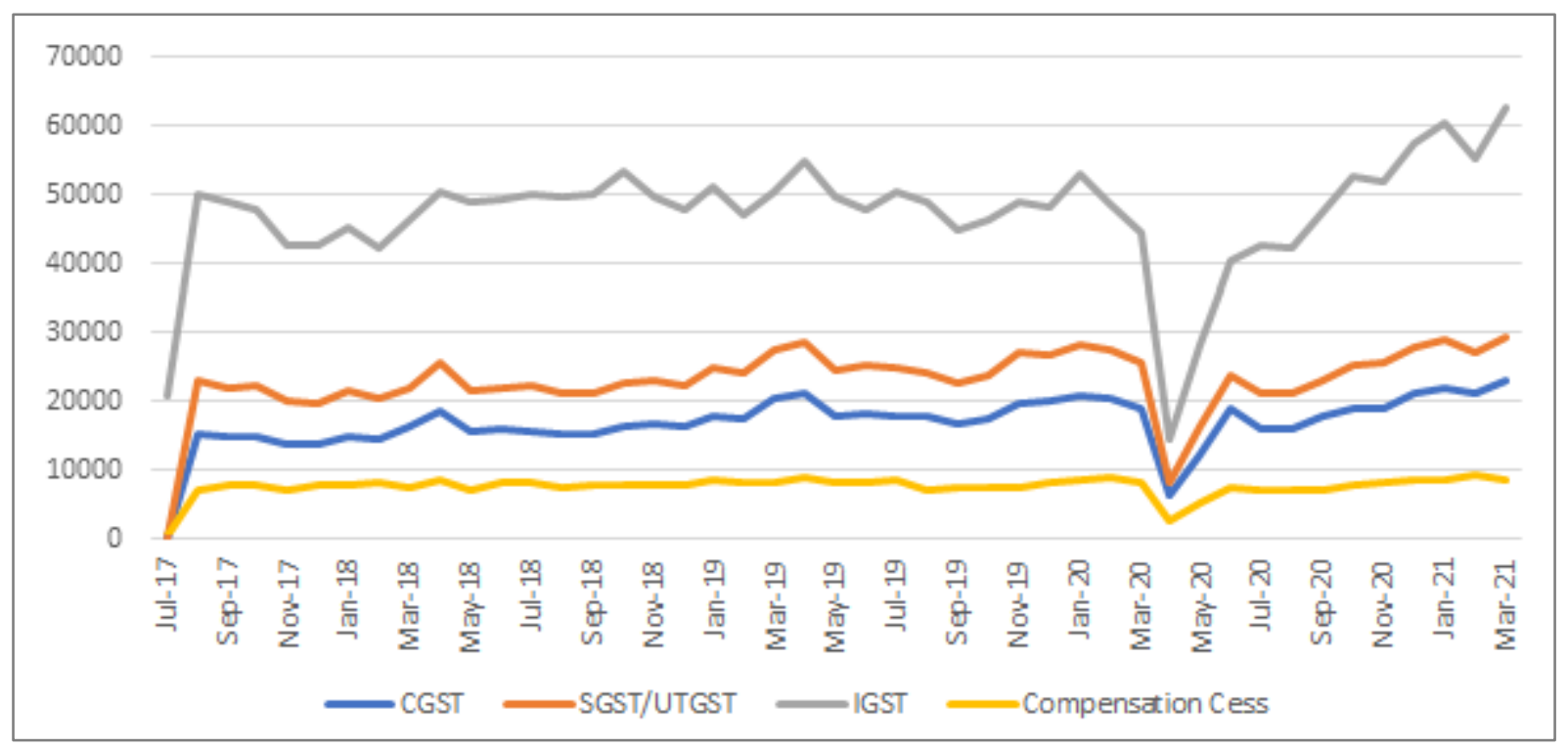

Figure 2. Trend of Component wise GST Collections in India

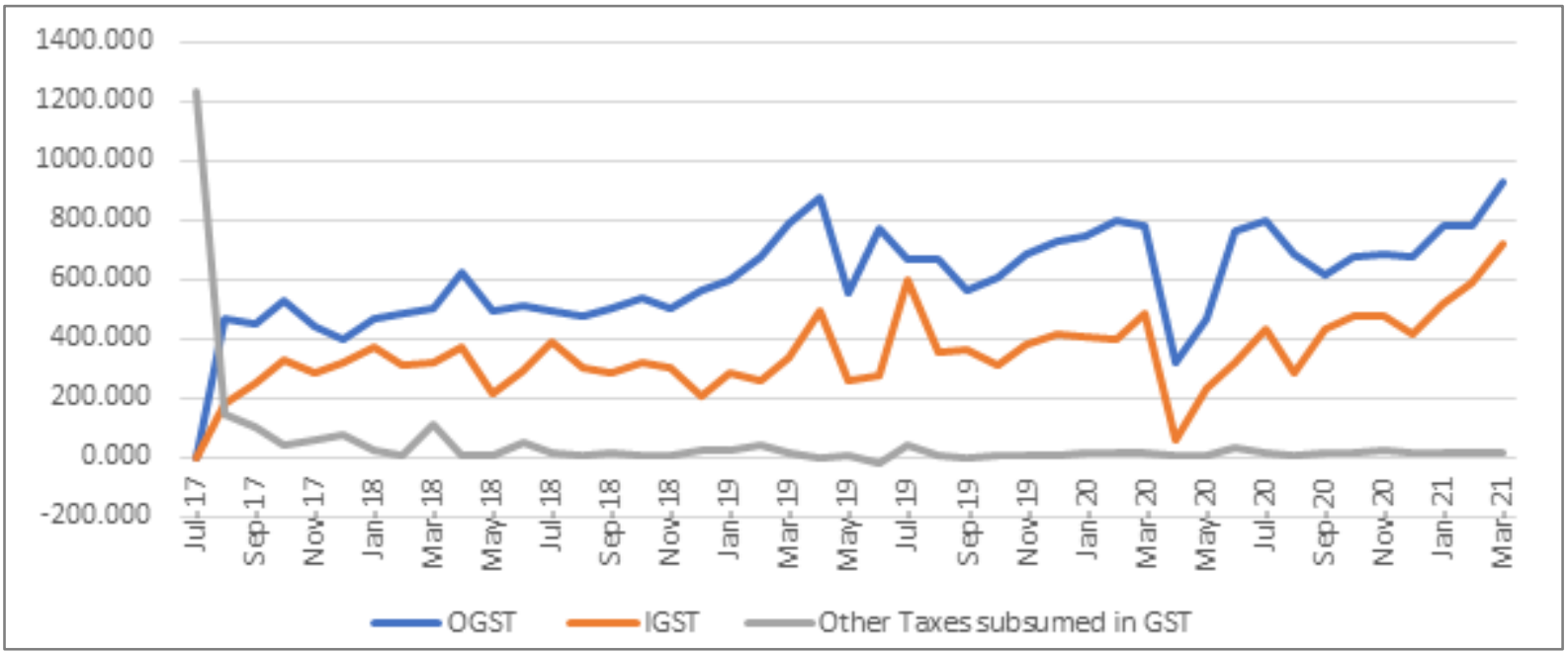

Figure 3. Trend of Component wise GST Collections in Odisha

Table-3 presents the growth of goods and services tax revenue in India since its implementation. The tax revenue is lowest in the month of April 2020 i.e., Rs. 32172 crores and is obvious because of outbreak of Corona virus and subsequent lock down, shut down of business activities. The highest growth in monthly collection of revenue is witnessed in the month of May and June 2020 because of outstanding GST payment of previous months. The maximum GST revenues is collected during March 2021 since its introduction. The growth rate GST revenue was (-) $41 \%,(-) 8 \%, 8 \%$ and $14 \%$ in the four quarters respectively during 2020-21, as compared to four quarters of year 2019-20, which shows the collection efficiency and growth of economy as a whole.

Figure-2 clearly indicates that collection of compensation cess, CGST and SGST/UTGST are uniform throughout the period while the revenue from IGST is collected on inter-state supply and import varies disproportionately and shows an increasing trend.

Table-4 shows the goods and services tax revenue collection of Odisha since application. It includes Odisha Goods and Services Taxes, IGST and all other taxes that were imposed by the State Government and now subsumed in GST. It also shows similar pattern of growth over the months as witnessed in all India revenue. The revenue collection decreases up to $70.3 \%$ in the month of April 2020 as compared to March 2020. The average OGST collection is Rs. 603 crore and average total GST collections is Rs. 1003 crore. Figure- 3 shows a uniform pattern of OGST and IGST collection in Odisha while other taxes that are subsumed in GST, shows a decreasing trend. 
Table 4. Growth of Component wise GST Collections in Odisha (Rupees in Crore)

\begin{tabular}{|c|c|c|c|c|c|}
\hline Year & SGST (OGST) & IGST & Others & Total & M-O-M Change \\
\hline Jul-17 & 0.112 & 0.000 & 1234.709 & 1234.822 & \\
\hline Aug-17 & 466.929 & 182.260 & 147.743 & 796.932 & $-35.5 \%$ \\
\hline Sep-17 & 451.703 & 251.797 & 105.826 & 809.327 & $1.6 \%$ \\
\hline Oct-17 & 531.106 & 331.197 & 39.849 & 902.152 & $11.5 \%$ \\
\hline Nov-17 & 440.428 & 282.893 & 59.538 & 782.859 & $-13.2 \%$ \\
\hline Dec-17 & 402.489 & 323.681 & 74.068 & 800.238 & $2.2 \%$ \\
\hline Jan-18 & 469.549 & 370.559 & 26.655 & 866.763 & $8.3 \%$ \\
\hline Feb-18 & 483.775 & 314.072 & 9.126 & 806.973 & $-6.9 \%$ \\
\hline Mar-18 & 503.846 & 320.874 & 112.218 & 936.938 & $16.1 \%$ \\
\hline Apr-18 & 622.063 & 369.983 & 7.348 & 999.393 & $6.7 \%$ \\
\hline May-18 & 492.691 & 217.198 & 6.568 & 716.456 & $-28.3 \%$ \\
\hline Jun-18 & 514.533 & 293.141 & 46.763 & 854.438 & $19.3 \%$ \\
\hline Jul-18 & 492.498 & 390.355 & 19.471 & 902.324 & $5.6 \%$ \\
\hline Aug-18 & 477.308 & 307.087 & 7.483 & 791.877 & $-12.2 \%$ \\
\hline Sep-18 & 507.083 & 286.172 & 19.460 & 812.715 & $2.6 \%$ \\
\hline Oct-18 & 535.295 & 323.209 & 9.547 & 868.052 & $6.8 \%$ \\
\hline Nov-18 & 504.752 & 300.283 & 8.540 & 813.576 & $-6.3 \%$ \\
\hline Dec-18 & 563.339 & 206.775 & 25.445 & 795.559 & $-2.2 \%$ \\
\hline Jan-19 & 595.439 & 287.801 & 21.413 & 904.653 & $13.7 \%$ \\
\hline Feb-19 & 672.990 & 260.397 & 39.247 & 972.634 & $7.5 \%$ \\
\hline Mar-19 & 790.543 & 339.066 & 14.703 & 1144.313 & $17.7 \%$ \\
\hline Apr-19 & 875.421 & 498.318 & 2.049 & 1375.788 & $20.2 \%$ \\
\hline May-19 & 551.758 & 261.529 & 4.159 & 817.447 & $-40.6 \%$ \\
\hline Jun-19 & 775.753 & 276.649 & -18.217 & 1034.185 & $26.5 \%$ \\
\hline Jul-19 & 669.613 & 598.664 & 44.513 & 1312.790 & $26.9 \%$ \\
\hline Aug-19 & 665.152 & 356.463 & 7.220 & 1028.835 & $-21.6 \%$ \\
\hline Sep-19 & 560.184 & 363.216 & 1.827 & 925.228 & $-10.1 \%$ \\
\hline Oct-19 & 610.509 & 307.695 & 6.740 & 924.944 & $0.0 \%$ \\
\hline Nov-19 & 685.250 & 377.468 & 5.543 & 1068.261 & $15.5 \%$ \\
\hline Dec-19 & 729.199 & 419.764 & 5.165 & 1154.128 & $8.0 \%$ \\
\hline Jan-20 & 743.125 & 407.869 & 14.338 & 1165.332 & $1.0 \%$ \\
\hline Feb-20 & 802.446 & 398.735 & 12.474 & 1213.655 & $4.1 \%$ \\
\hline Mar-20 & 784.812 & 483.929 & 15.986 & 1284.727 & $5.9 \%$ \\
\hline Apr-20 & 316.289 & 59.764 & 5.715 & 381.769 & $-70.3 \%$ \\
\hline May-20 & 467.820 & 231.252 & 6.333 & 705.405 & $84.8 \%$ \\
\hline Jun-20 & 760.740 & 319.475 & 30.939 & 1111.154 & $57.5 \%$ \\
\hline Jul-20 & 801.576 & 435.587 & 15.446 & 1252.609 & $12.7 \%$ \\
\hline Aug-20 & 683.646 & 286.917 & 10.720 & 981.283 & $-21.7 \%$ \\
\hline Sep-20 & 619.137 & 437.487 & 14.818 & 1071.442 & $9.2 \%$ \\
\hline Oct-20 & 675.828 & 480.836 & 12.428 & 1169.092 & $9.1 \%$ \\
\hline Nov-20 & 683.945 & 477.894 & 23.166 & 1185.005 & $1.4 \%$ \\
\hline Dec-20 & 678.498 & 414.423 & 19.226 & 1112.147 & $-6.1 \%$ \\
\hline Jan-21 & 777.710 & 516.117 & 14.325 & 1308.152 & $17.6 \%$ \\
\hline Feb-21 & 781.06 & 590.543 & 17.638 & 1389.241 & $6.2 \%$ \\
\hline Mar-21* & 925.681 & 724.000 & 19.320 & 1669.001 & $20.1 \%$ \\
\hline Average & 603.192 & 348.520 & 51.724 & 1003.436 & \\
\hline
\end{tabular}

Source: www.odishatax.gov.in/revenue reports

*Revenue for the month of March 2021 has been taken as gross of actual tax deposited by the dealers. 


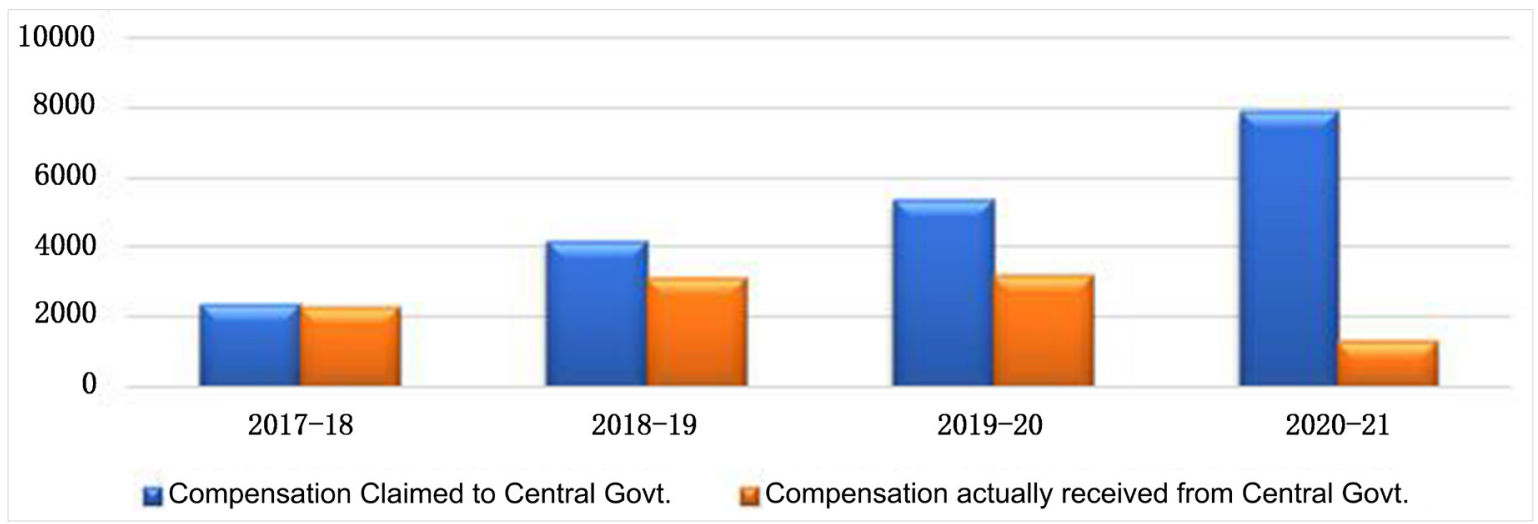

Figure 4. Compensation Cess Received against Claim by Odisha

As per the terms of the GST Act, the Central Government shall compensate the State Governments for loss of revenue due to implementation of GST for first five years. Every month, each state has to prepare and calculate the loss of revenue in their concerned state and demand to the Central Government. Table-5 and Figure-4 shows the compensation cess demanded and actually received from the Central Government by Odisha during last four years. It is prominent to mentioned here that the percentage of compensation cess received against demand has decreased year after year. On an average only $50 \%$ of required compensation cess has been released by the Centre.

Table 5. Status of Settlement of Compensation Cess to Odisha (Rupees in Crores)

\begin{tabular}{|c|c|c|c|c|}
\hline Year & Claimed & Received & Realised \% & Due \\
\hline $2017-18$ & 2350.72 & 2264.00 & $96 \%$ & 86.72 \\
\hline $2018-19$ & 4185.75 & 3145.00 & $75 \%$ & 1040.75 \\
\hline $2019-20$ & 5356.57 & 3204.70 & $60 \%$ & 2151.87 \\
\hline $2020-21$ & $7,911.47$ & $1,282.08$ & $16 \%$ & 6629.40 \\
\hline Total & 19804.51 & 9895.777 & $50 \%$ & 9908.736 \\
\hline
\end{tabular}

Source: cbic.gov.in and odishatax.gov.in

\section{Forecasting Revenue using ETS functions:}

I have used exponential triple smoothing (ETS) functions for predicting the future indirect tax revenue from the existing time series data of indirect tax before introduction of GST i.e., from 2013 to 2017. As this technique uses advanced machine learning algorithms and is considered a rule of thumb technique, rather than one based on theoretical foundations and has often been over-emphasized by practitioners. Triple exponential smoothing with multiplicative seasonality is given by the formulas:

$$
b_{0}=\frac{1}{L}\left(\frac{x_{L+1}-x_{1}}{L}+\frac{x_{L+2}-x_{2}}{L}+\cdots+\frac{x_{L+L}-x_{L}}{L}\right.
$$

Since, indirect tax revenue is primarily based on consumption and supply, its flow is subject to seasonal variation. Hence, setting the initial estimates for the seasonal indices $\mathrm{C}_{\mathrm{i}}\left\{\right.$ \displaystyle $\left.\mathrm{c}_{-}\{\mathrm{i}\}\right\}$ for $\mathrm{i}=1,2,3, \ldots \ldots \ldots \mathrm{L} \quad\{$ displaystyle $\mathrm{i}=1,2$, ldots, $\mathrm{L}\}$ is a bit more involved. In our data, \{ldisplaystyle $\mathrm{N}\} \mathrm{N}$ is the number of complete cycles or year, then:

$$
C_{i}=\frac{1}{N} \sum_{j=1}^{N} \frac{x L(j-1)+i}{A j} \text { for } i=1,2, \ldots \ldots \ldots, L
$$

Where,

$$
A_{i}=\frac{\sum_{i=1}^{L} x L(j-1)+i}{L} \text { for } i=1,2, \ldots \ldots \ldots, N
$$

Note that $\left\{\right.$ displaystyle $\left.\mathrm{A} \_\{\mathrm{j}\}\right\} \mathrm{A}_{\mathrm{j}}$ is the average value of $\{\mid$ displaystyle $x\} x$ in the $\left\{\right.$ displaystyle $\mathrm{j}^{\wedge}\{\mid \operatorname{text}\{$ th $\left.\}\}\right\} \mathrm{j}^{\text {th }}$ year.

Table- 6 presents the forecasted indirect tax revenue on the basis of old indirect tax revenue which are subsumed in this new GST laws. Column-2 shows the actual tax revenue from old indirect tax system from 2013 to 2017. Column-3 and Column-4 represent the actual indirect tax revenue of Odisha with and without including compensation cess from Central Government. Column-5 shows the forecasted value of indirect taxes for the year 2017 to 2023. 
Table 6. Forecasting Indirect Tax Revenue, Odisha (rupee in crore)

\begin{tabular}{|c|c|c|c|c|c|c|}
\hline $\begin{array}{c}\text { Period } \\
\text { ending } 31 \\
\text { Mar }\end{array}$ & $\begin{array}{l}\text { Indirect Tax } \\
\text { before GST }\end{array}$ & $\begin{array}{l}\text { Indirect Tax after GST } \\
\text { without Compensation }\end{array}$ & $\begin{array}{l}\text { Indirect Tax after GST } \\
\text { with Compensation }\end{array}$ & $\begin{array}{c}\text { Forecasted } \\
\text { Indirect Tax on } \\
\text { the basis of tax } \\
\text { before GST }\end{array}$ & Statistic & Value \\
\hline (1) & (2) & (3) & (4) & (5) & (6) & (7) \\
\hline 2013 & 9233.710 & & & & Alpha & 0.25 \\
\hline 2014 & 10036.710 & & & & Beta & 0.00 \\
\hline 2015 & 10756.290 & & & & Gamma & 0.00 \\
\hline 2016 & 11049.340 & & & & MASE & 0.20 \\
\hline 2017 & 11834.493 & & & 11834.493 & SMAPE & 0.01 \\
\hline 2018 & & 10652.813 & 12916.813 & 12401.916 & MAE & 127.23 \\
\hline 2019 & & 10575.989 & 13720.989 & 13017.813 & RMSE & 153.99 \\
\hline 2020 & & 13305.320 & 16510.020 & 13633.709 & & \\
\hline 2021 & & 13056.359 & 14338.439 & 14249.606 & & \\
\hline 2022 & & & & 14865.503 & & \\
\hline 2023 & & & & 15481.399 & \multirow{3}{*}{\multicolumn{2}{|c|}{$95 \%$ level of significance }} \\
\hline & alue & -3.197 & 1.677 & & & \\
\hline \multicolumn{2}{|c|}{ P-Value } & 0.049 & 0.192 & & & \\
\hline
\end{tabular}

Source: Author's calculation

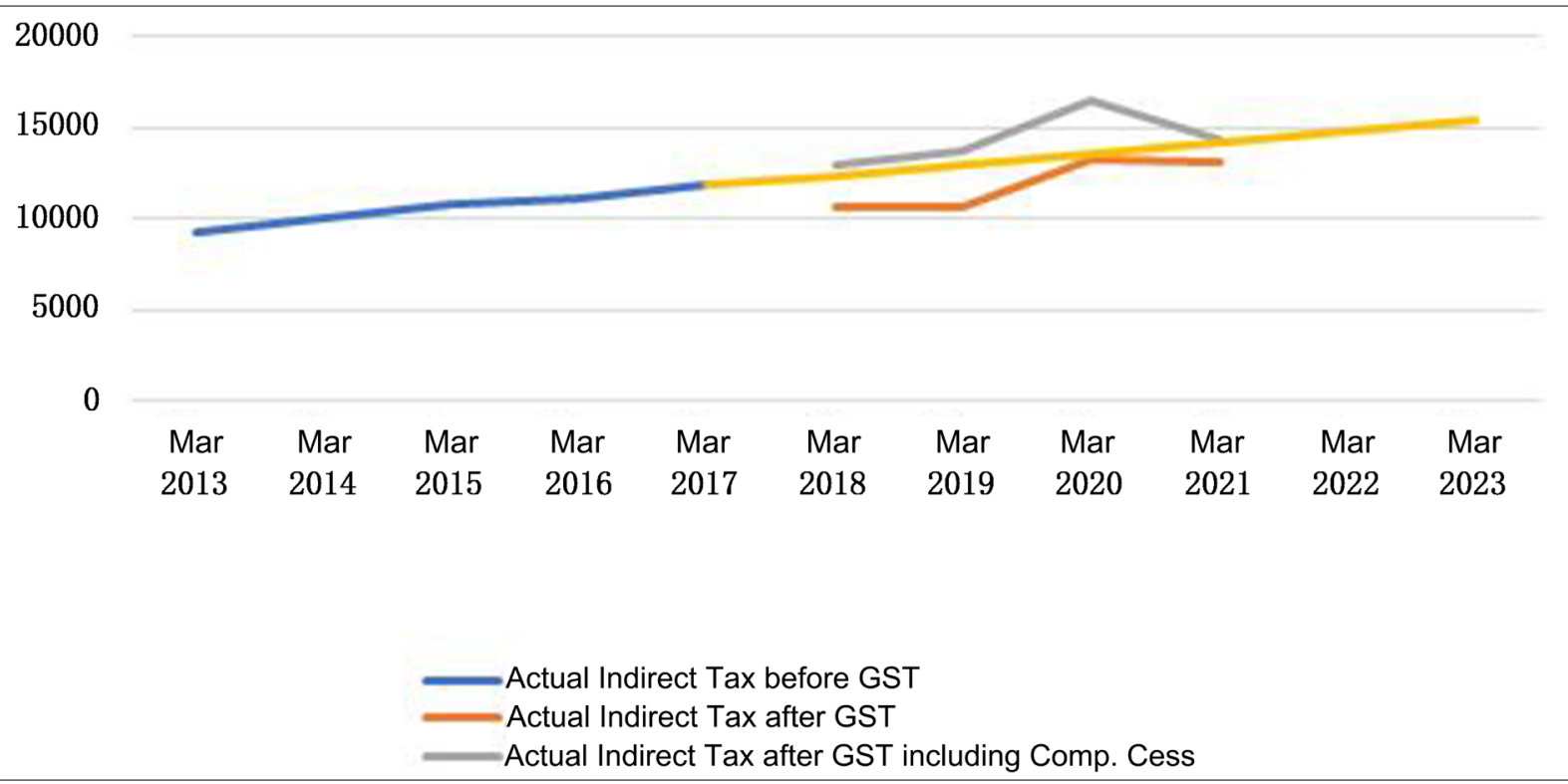

Figure 5. Forecasted Indirect Tax Revenue in Odisha

When we compare the forecasted revenue with the actual indirect tax revenue during GST without considering the compensation cess, the $\mathrm{p}$ value is less than 0.05 hence the null hypothesis stands rejected. We can conclude that there exists significant difference between estimate value and actual revenue. But if we considered revenue with compensation cess, then $\mathrm{p}$ value is more 0.05 , hence we can conclude that there is no significance difference between actual and forecasted revenue.
It is clear from figure-5 that actual indirect tax revenue after GST is little bit lower than the forecasted value. If we considered the actual indirect tax collection including compensation cess for the said period then, it is little bit more or equal to the forecasted value.

Table-7 shows the forecasted monthly indirect tax revenue on the basis of monthly tax collected under goods and services tax since July 2017 . The forecasted value does not include the compensation cess. It shows an increasing trend over the years. 
Table 7. Forecasting Monthly Indirect Tax Revenue, Odisha (rupee in crore)

\begin{tabular}{|c|c|c|c|}
\hline Period & $\begin{array}{c}\text { Forecasted Indirect } \\
\text { Tax Revenue }\end{array}$ & Period & $\begin{array}{c}\text { Forecasted Indirect } \\
\text { Tax Revenue }\end{array}$ \\
\hline Apr-21 & 1249.378 & Apr-22 & 1334.257 \\
\hline May-21 & 1256.451 & May-22 & 1341.330 \\
\hline Jun-21 & 1263.525 & Jun-22 & 1348.404 \\
\hline Jul-21 & 1270.598 & Jul-22 & 1355.477 \\
\hline Aug-21 & 1277.671 & Aug-22 & 1362.550 \\
\hline Sep-21 & 1284.744 & Sep-22 & 1369.623 \\
\hline Oct-21 & 1291.818 & Oct-22 & 1376.697 \\
\hline Nov-21 & 1298.891 & Nov-22 & 1383.770 \\
\hline Dec-21 & 1305.964 & Dec-22 & 1390.843 \\
\hline Jan-22 & 1313.037 & Jan-23 & 1397.916 \\
\hline Feb-22 & 1320.111 & Feb-23 & 1404.990 \\
\hline Mar-22 & 1327.184 & Mar-23 & 1412.063 \\
\hline Total & $\mathbf{1 5 4 5 9 . 3 7 3}$ & & $\mathbf{1 6 4 7 7 . 9 2 1}$ \\
\hline
\end{tabular}

Source: Author's calculation

\section{Conclusion}

GST is no doubt a transparent and efficient tax system that will increase the tax base and revenue in the long run. Since its inception the revenue has increased but as expected. This may be because of inherent limitations of the system and outbreak of corona virus global pandemic. Any new system will take time to be cent percent result oriented and GST in India is going to celebrate its fourth anniversary on July 2021. During this short span of time, many changes and modifications have been incorporated to bring more transparency and efficiency in this system. The monthly GST revenues crossed above one lakh crore mark for India and one thousand mark for Odisha at a stretch for the last six months and a precipitous increasing trend over this period are clear indicators of rapid economic recovery post pandemic. Closer monitoring against fake-billing, deep data analytics using data from multiple sources including GST, Income-tax and Customs IT systems and effective tax administration have also contributed to the steady increase in tax revenue over last few months. So far as Odisha state is concerned, the GST is yet to give its expected results which is witnessed from the settlement of compensation cess over the years. The revenue loss is still continuing and the scheme of compensation is only for first five years which is going to end on July 2022. It is matter of concern for the state.

\section{Practical Implication}

This study will definitely contribute to the existing literature more prominently revenue implication after introduction of GST. Further, this study will provide ample evidence to the State to predict indirect tax revenue and reconsider the claim of compensation cess. It is also helpful to the policy formulators and tax authorities to prepare budget and revenue generation strategies according to the forecasted revenue.

\section{Scope for Further Study}

The present paper considered only total indirect tax revenue that are subsumed in GST. It also covers only one State Odisha and compares it with India. The results have limited use as it considers only selected variables. More variables like direct tax revenue, gross domestic product, number of tax payers, tax buoyancy, total indirect tax revenue, etc. may be considered to get more realistic results. Further, cross States analysis and multiple regression analysis would be more useful to policy formulators.

\section{Acknowledgement}

The author would like to thank Odisha State Higher Education Council, Department of Higher Education and Government of Odisha for OURIIP seed fund research support.

\section{REFERENCES}

[1] Alappatt M., Shaikh J. M., "Forthcoming procedure of goods and service tax (GST) in Malaysia," Issues in Business Management and Economics, vol. 2, no. 12, pp. 210-213, 2014. DOI: 10.15739/IBME.2014.008

[2] Beri Y., "Goods and Services Tax (GST) -A global scenario," International Journal of Social Science and Interdisciplinary Research (IJSSIR), vol. 6, no. 1, pp. 1-9.

[3] Bird Richard Miller, "The GST/HST: Creating an Integrated Sales Tax in a Federal Country," Rotman School of Management Working Paper No. 2115620, 2012. DOI: $10.2139 /$ ssrn. 2115620

[4] Chakraborty S., "A study on impact of Goods and Services Tax on Indian textile industry," Research Review International Journal of Multidisciplinary, vol. 3, no. 11, pp. 86-91, 2018. DOI: 10.5281/zenodo.1481899

[5] Charan P., Benjamin R., Khan Z. H., "Goods and Services Tax (GST) Bill'2016: Gearing up for the next big wave in the Indian Economy," International Journal of Scientific \& Engineering Research, vol. 8, no. 1, pp. 1454-1461, 2017.

[6] Garg M., Kumar M., "Indian tax structure and relevance of GST," International Journal of Advance Research and Innovative Ideas in Education, vol. 3, no. 4, pp. 2199-2205, 2017.

[7] Holla R., "SWOC analysis of Goods and Services Tax (GST): Implementation in India," International Journal of Current Research and Modern Education (IJCRME), vol. 1, no. 2, pp. 
229-236, 2017.

[8] Kawale P. S., Aher Y. L., "GST: An economic overview: Challenges and impact ahead," International Research Journal of Engineering and Technology (IRJET), vol. 04, no. 04, pp. 2760-2763, 2017.

[9] Khoja I. A., Khan N. A., "Goods and services tax, cascading, and revenue performance: Analyzing Indian commodity taxation market," Journal of Public Affairs, vol. 20, no. 3, pp. 1-11, 2020. DOI: 10.1002/pa.2109

[10] Leena, Sameena, "Impact of Goods and Services Tax on Indian Economy," KAAV International of Economics, Commerce and Business Management, vol. 4, no. 4, pp, 422-427, 2017

[11] Mansoor N. H. A., Mohamed I. S., Ling L. M., Kasim, N., "Information technology sophistication and Goods and Services Tax in Malaysia," Procedia Economics and Finance, vol. 35, pp. 2-9, 2016. DOI: $10.1016 / \mathrm{S} 2212-5671(16) 00003-4$

[12] Mukherjee S., "Present state of goods and services tax (GST) reform in India (TTPI Working Paper 6/2015)," Tax and Transfer Policy Institute, 2015. https://ideas.repec.org/p/npf/wpaper/15-154.html

[13] Mukherjee S., "Goods and Services Tax efficiency across Indian States: Panel stochastic frontier analysis," Indian Economic Review, vol. 55, no. 2, pp. 225-251, 2020. DOI: 10.1007/s41775-020-00097-z

[14] Mukherjee S., "Pandemic and GST Revenue: An Assessment for Union and States (NIPFP Working Paper No. 327)," National Institute of Public Finance and Policy, 2020. https://www.nipfp.org.in/media/medialibrary/2020/01/WP 327_2020.pdf

[15] Mukherjee S., "Performance Assessment of Indian GST: State-level Analysis of Compliance Gap and Revenue Growth (NIPFP Working Paper No. 301)," National Institute of Public Finance and Policy, 2020. https://www.nipfp.org.in/media/medialibrary/2020/01/WP 301_2020.pdf

[16] Mukherjee S., "Possible impact of withdrawal of GST compensation post GST compensation period on Indian state finances (NIPFP Working Paper No. 291)," National Institute of Public Finance and Policy, 2020. https://www.nipfp.org.in/media/medialibrary/2020/01/WP 291_2020.pdf

[17] Nayaka, B., Panduranga V. P., "Analysis of Impact of Goods and Services Tax on Indirect Taxes of Karnataka State," The Indian Economic Journal, vol. 67, no. 1-2, pp. 117-127,

\section{DOI: $10.1177 / 0019466220941665$}

[18] Nayyar A., Singh I., "A comprehensive analysis of Goods and Services Tax (GST) in India," Indian Journal of Finance, vol. 12, no. 2, pp. 57-71, 2018. DOI: 10.17010/ijf/2018/v12i2/121377

[19] Pandey M., "Impact of goods and service tax (GST) on Indian tax structure," International research journal of management, IT and social sciences, vol. 4, no. 3, pp. 22-33, 2017.

[20] Patil S., "Myths and Reality of Goods and Services Tax (GST): A study," PRATIBHA: International Journal of Science, Spirituality, Business and Technology (IJSSBT), vol. 5, no. 2, pp. 47-52, 2017.

[21] Pegu B., "The proposed GST (Goods and Services Tax) and Indian economy," International Journal of Interdisciplinary Research in Science Society and Culture, vol. 3, no. 1, pp. 65-71, 2017.

[22] Purohit M. C., Purohit V. K., "Goods and services tax in India: An empirical analysis of revenue implications," The Indian Economic Journal, vol. 58, no. 1, pp. 33-59, 2010. DOI: $10.1177 / 0019466220100104$

[23] Rao M. G., "Goods and Services Tax: Some Progress towards Clarity," Economic and Political Weekly, vol. 44, no. 51, pp. 8-11, 2009.

[24]Rao M. G., "Goods and Services Tax: A Gorilla, Chimpanzee or a Genus like 'primates'?," Economic and Political Weekly, vol. 46, no. 7, pp. 43-48, 2011.

[25] Sanusi S., Omar N., Sanusi Z. M., "Goods and Services Tax (GST) Governance in the Malaysian new tax environment," Procedia Economics and Finance, vol. 31, pp. 373-379, 2015. DOI: $10.1016 / \mathrm{S} 2212-5671(15) 01212-5$

[26] Singh A., "Goods and Services Tax in India: A Note," International Journal of Social Science and Development Policy, vol. 3, no. 2, pp. 131-135, 2017.

[27] Stewart M. F., Shannon J. H., McKenzie M. D., “A Variable Rate Goods and Services Tax (GST) for Australia?," Economic Papers: A Journal of Applied Economics and Policy, vol.18, no. 2, pp. 78-94, 1999.

[28] Tewari V. K., "Goods and service tax," GST Simplified Tax System: Challenges and Remedies, vol. 1, no. 1, pp.173-176, 2018.

[29] Tiwari H, Singh S. N., "Goods and Service Tax: Economic Revival of India,” Paradigm, vol. 22, no. 1, pp. 17-29, 2018. DOI: $10.1177 / 0971890718758198$ 